\title{
Intervenção Política, Imprensa e Democracia: os Tijolaços de Leonel Brizola ${ }^{1}$
}

Américo Freire* Flavia Azevedo**

Resumo: Leonel Brizola, nas décadas de 1980 e 1990, valendo-se do prestígio do seu nome junto a correligionários trabalhistas, levantou recursos para publicar sistematicamente artigos na grande imprensa brasileira, os quais passaram a ser conhecidos como tijolaços ou tijolões. Durante cerca de quinze anos, Brizola usou e abusou daqueles espaços, seja combatendo seus inimigos políticos, estivessem eles à direita ou à esquerda, seja prestando contas de sua administração como governador do Rio de Janeiro, ou ainda divulgando o ideário nacionalista do novo trabalhismo. Por variadas vezes, os textos assinados por Brizola entraram em rota de colisão direta com a linha editorial dos jornais que publicavam seus tijolaços. Neste artigo, ao lado de apresentarmos um roteiro de investigação com vistas a um melhor tratamento analítico desse importante conjunto documental, abordamos algumas questões específicas que dizem respeito às relações de Brizola com a mídia, e à maneira pela qual suas intervenções serviram de base para a construção de um discurso próprio no processo de democratização brasileiro.

Palavras-chave: História Política, Leonel Brizola, Democratização Brasileira, Imprensa.

\footnotetext{
* Professor do Programa de Pós-Graduação em História, Política e Bens Culturais do CPDOC/FGV e pesquisador do CNPq.

** Socióloga. Bacharel em Ciências Sociais pela Escola de Ciências Sociais da FGV.
} 
Nos últimos tempos, na esteira da renovação dos estudos acerca da história do trabalhismo no Brasil, tem havido um avanço considerável da literatura acerca de diferentes aspectos da carreira política de Leonel Brizola, seja em relação às suas políticas públicas à frente da prefeitura de Porto Alegre e dos governos no Rio Grande do Sul e no Rio de Janeiro, seja como líder do nacionalismorevolucionário da conjuntura pré-golpe civil-militar de 1964, seja enfim como principal artífice do "novo trabalhismo" no processo de democratização brasileira dos anos de 1980 e 1990². Sua morte, em 2004, ensejou, para além das homenagens de praxe, a publicação de alguns trabalhos importantes a respeito de sua trajetória, destacando-se, entre outros, um volume da coleção Parlamentares gaúchos, por iniciativa da Assembleia Legislativa do Estado do Rio Grande do Sul - no qual estão reunidos os pronunciamentos de Brizola como deputado estadual e federal -, assim como a alentada e bem documentada biografia escrita pelo jornalista F. C. Leite Filho intitulada El caudilho: Leonel Brizola: um perfil biográfico3.

Nas idas e vindas de seus cinquenta anos de vida pública, cremos que é possível identificar dois pontos de inflexão ascendente na carreira de Brizola como líder político: a Campanha da Legalidade, na qual assume a vanguarda nas lutas pelas transformações sociais e políticas no país, vindo a congregar uma ampla frente das esquerdas; e sua vitória à governadoria do estado no Rio de Janeiro, em 1982, quando veio a derrotar simultaneamente as máquinas do amaralismo, apoiada pelo governo federal, e a do chaguismo, detentora do governo estadual. Nessas duas ocasiões, Brizola estabeleceu uma importante conexão com variados veículos de comunicação, valendo-se dos atributos de sua oratória para granjear apoio junto à opinião pública. No primeiro caso, o rádio foi o seu principal instrumento de pregação política; já no segundo, utilizou-se dos debates televisivos e da imprensa escrita não apenas para conquistar a vitória eleitoral, como também para denunciar a fraude eleitoral levada adiante pelos seus adversários políticos no chamado caso Proconsult. Porquanto a recente literatura já tenha feito menção à maneira pela qual Brizola valeu-se dos meios de comunicação para firmar posições no cenário nacional, até o momento, não há, no entanto, estudos mais sistemáticos que tomem como objeto de 
análise as relações entre o líder trabalhista e a mídia. Material para pesquisa não falta, já que o próprio Brizola se aprazia em alimentar a tese de que sempre fora vítima de campanha diuturna dos meios de comunicação contra ele e seu partido.

Em 1984, já na condição de governador do estado do Rio de Janeiro, Brizola tomou a decisão de voltar a estabelecer um contato direto com a opinião pública por meio da publicação de artigos semanais na grande imprensa, os quais eram custeados pelos seus correligionários. No Rio de Janeiro, esses artigos foram publicados principalmente no Jornal do Brasil e n'O Globo, sendo reproduzidos por veículos de outros estados e no Distrito Federal. Por meio deles, Brizola abre uma janela para defender seu governo, seu projeto político e, fiel ao seu conhecido estilo de líder revolucionário, atacar impiedosamente seus adversários políticos, inclusive os próprios donos dos jornais que publicavam os artigos. Não por acaso, eles passaram a ser conhecidos como tijolaços ou tijolões, em função da maneira desabrida e desassombrada com a qual seu autor intervinha na cena política.

As intervenções de Brizola nesses espaços serão examinadas da seguinte maneira. Em primeiro lugar, serão exploradas algumas questões relativas ao formato e à linguagem dos tijolaços, tendo em vista inferir acerca do caráter próprio dessas publicações no conjunto das intervenções públicas do ator em tela, assim como acompanhar as possíveis modulações e mudanças na narrativa brizolista. Em seguida, iremos nos voltar para uma análise dos conteúdos recorrentes nos materiais em questão, quando será dada especial atenção a um tema de particular predileção de Brizola: suas relações com a mídia. Concluímos com algumas reflexões gerais em torno do significado do estudo dessa fonte para um melhor entendimento acerca do papel que Brizola assumiu no processo de democratização brasileira.

\section{Uma tribuna nos jornalões}

A literatura a respeito de Leonel Brizola é unânime em apontar um traço recorrente da sua persona política: seu enfado pelas regras e pela organização burocrática e seu gosto pela improvisação. Tal 
traço de personalidade do líder foi transposto diretamente para o seu partido, o Partido Democrático Trabalhista, daí explica-se a atávica dificuldade da agremiação em pôr seus documentos em ordem. Uma prova inconteste disso diz respeito aos tijolaços de Brizola - nem o partido, nem seus militantes tiveram a trivial ideia de reuni-los em um volume, por mais simples que fosse. Daí o inevitável: há dúvidas relativas não só ao número total de tijolaços, mas também quanto à sua duração. Por ora, fiquemos com alguns dados apresentados por Apio Gomes, militante do partido, no site da agremiação. Segundo ele, em artigo sugestivamente chamado de Tijolaço para principiantes, foram publicados entre 1984 e 1998, ou seja, em 14 anos, um total de 456 tijolaços, divididos em 1142 matérias ${ }^{4}$.

Em razão disso, também não surpreende o fato deles até agora não servirem de base para a literatura acadêmica - ou mesmo a partidária - sobre Brizola ou sobre o fenômeno do brizolismo. Quando muito, são feitas algumas menções esparsas sobre as publicações, como o fazem, por exemplo, Mônica Rodrigues, em artigo em que trata das relações de Brizola com a mídia, e F. C. Leite Filho na referida biografia do líder trabalhista ${ }^{5}$. Já no vasto mundo dos blogues da internet, o termo vem sendo utilizado por nada mais, nada menos, do que pelo pretenso sucessor do líder trabalhista - o deputado federal pelo Rio de Janeiro Brizola Neto. Criado para reverenciar a memória do avô, o blogue intitulado Tijolaço, que conta com a colaboração de ex-assessores de Brizola, tem servido cada vez mais para divulgar as ideias e as atividades do neto ${ }^{6}$.

No momento da pesquisa, em que ainda estamos à cata da totalidade das publicações - também marcadas por uma certa irregularidade, como não poderia deixar de ser - optamos neste texto por concentrar o foco de análise no exame de textos relativos a duas conjunturas marcantes na longa trajetória do líder trabalhista, a saber: aos anos que correspondem ao fim do regime militar e à implantação da Nova República - quando é ator em plena ascensão política e candidato à presidência da República - e ao início dos anos 90 - quando Brizola, depois de ter sido derrotado nas eleições presidenciais de 1989, exerce a segunda governadoria no Rio de Janeiro, ainda de olho no Planalto. Nesse segundo caso, trata-se de uma liderança que enfrenta grandes dificuldades em se manter como 
alternativa de poder, seja pela ascensão de Lula e do PT no campo das esquerdas, seja pelos inúmeros problemas e desafios que se interpuseram em seu novo governo no Rio de Janeiro, relacionados com a governadoria do Rio de Janeiro, particularmente aqueles ligados à violência urbana.

Passemos, pois, a levar adiante uma das etapas da operação historiográfica, a qual, há tempos, costumava ser chamada de crítica interna das fontes, na qual são verificados aspectos como formato, seções e linguagem.

$\mathrm{Na}$ pesquisa até agora realizada, verifica-se que a fonte em questão pouco foi alterada em seu formato. Em geral, os tijolaços ocupavam uma coluna por inteiro de uma das páginas dedicadas à política interna nos dois principais jornais do Rio de Janeiro - $O$ Globo e Jornal do Brasil. A esse respeito, cabe o registro de que pudemos aferir uma divulgação mais amiúde desse tipo de publicação no Jornal do Brasil, fato esse que não se deve estranhar dada a histórica relação de conflito que marcou as relações de Brizola e outros líderes trabalhistas com $O$ Globo. Em seguida, iremos retomar esse ponto.

O tijolaço era composto da seguinte maneira: dois títulos de abertura (um de referência e outro relativo ao principal tema a ser tratado); um ou dois textos nos quais eram tratados os assuntos de fundo, acrescidos de algumas notícias pontuais relativas às iniciativas do governo ou do partido. Em sua grande maioria, os textos terminavam com um até breve do autor e com a assinatura do mesmo. Registre-se que se trata de uma assinatura manuscrita.

Com o decorrer do tempo, a titulação passou por algumas alterações. Em um primeiro momento, quando do seu lançamento, os textos intitulavam-se Esclarecendo a população. Logo em seguida, já em 1985-1986, passaram a ser intitulados Governador Leonel Brizola ou Prestando contas à população. Na prática, essa mudança não alterava em nada o espírito da criação daquele instrumento, qual seja o de dar a palavra à autoridade pública estadual. Daí a ênfase em questões de natureza político-administrativas em detrimento de questões político-partidárias.

Ao fim dos anos 80, com Brizola já livre de atribuições de governo e em plena campanha às eleições presidenciais, as publicações ganharam um formato de cunho mais personalizado - são intituladas 
tão somente Leonel Brizola e é colocado um desenho pequeno com o rosto de Brizola. A assinatura manuscrita é mantida. Nos anos 90, esse formato consolida-se, fazendo com que os tijolaços passem a representar, nada mais nada menos, do que a palavra do líder seja ele governador de estado, presidente do PDT ou candidato presidencial.

No que concerne à linguagem, tratemos por ora de nos concentrar no estilo do ex-governador, deixando para depois uma análise mais sistemática sobre os conteúdos do seu discurso. A esse respeito, ao se examinar o material nas duas conjunturas já mencionadas, também se pode verificar que houve alguns ajustes que se referem às oscilações da trajetória política de Brizola.

$\mathrm{Na}$ vida política brasileira, Brizola apresentava em sua fala um linguajar próprio prenhe de imagens regionais por vezes associadas a espanholismos típicos dos políticos gaúchos da fronteira. Paralelamente, utilizava-se de imagens e ditos populares para, com uma ampla dose de sarcasmo, assacar apelidos nos seus adversários, tais como quando chamou Moreira Franco de gato angorá (fazendo menção aos cabelos brancos do mesmo). Determinadas ocasiões, geralmente às por ele vistas como graves, valia-se de expressões bíblicas, fazendo as vezes de um pastor protestante. Em sua pregação, princípios e valores cristãos eram enfatizados como meio de legitimação de seu discurso. A solidariedade para com o próximo e a oposição bem $\mathrm{x}$ mal eram frequentemente resgatadas na linguagem dos tijolaços ${ }^{7}$. Quando queria denunciar a traição ou a hipocrisia de um adversário político, o tratava como fariseu. Por sinal, há um tijolaço intitulado Carta a um Fariseu, publicado em 13/09/1992, no qual Brizola acusa impiedosamente Luiz Inácio Lula da Silva de se aproximar de Roberto Marinho e das organizações Globo.

$\mathrm{Na}$ pesquisa, procura-se investigar se o veículo utilizado pelo protagonista - no caso a grande imprensa - teve algum impacto direto na mudança do seu discurso. Dito de outra forma: sua linguagem escrita mostra-se mais domesticada do que a utilizada nos programas do partido ou em debates transmitidos pela TV? Ao assumir altos cargos públicos, como a governadoria do Rio de Janeiro, em duas ocasiões, Brizola curva-se ao uso de um dialeto político-administrativo? Até o momento, cremos que é possível 
responder a essas duas questões positiva e negativamente. Senão vejamos.

Fernando Brito, um dos principais assessores de Brizola, assim tratou da linguagem dos tijolaços:

Em consequência, os artigos acabavam moldados à semelhança de sua oratória: períodos longos, metáforas, muitas referências históricas e uso de palavras que, conquanto expressassem corretamente a ideia, muitas vezes eram incompreensíveis ao leitor menos preparado: contubérnio (mancebia, convivência promíscua), despifarro (espanholismo que significa desperdício), procrastinação (protelação) e outras $[. . .]^{8}$ (BRITO, 2011, s.p.)

Portanto, como se pode perceber, Brito vê nos tijolaços um mero prolongamento da oratória do líder. Em nossas pesquisas pudemos verificar que, pelo menos em um primeiro momento, Brizola adota um tom mais formal, mostrando-se cuidadoso e parcimonioso no enfrentamento direto contra seus adversários político-partidários, revestindo-se fundamentalmente da autoridade de governador de estado. Isso não significaria, no entanto, que não responderia às críticas conduzidas contra ele e seu governo, principalmente pela mídia. No caso, em 1984, quando do lançamento dos tijolaços, defende-se fundamentalmente de artigos sistemáticos publicados contra sua administração no Estado de São Paulo e no Jornal do Brasil.

Os primeiros tijolaços de Brizola são marcados pela linguagem austera de um homem imbuído da responsabilidade de governar. São peças de cunho mais defensivo, alertando a população das manipulações da grande imprensa contra ele e seu governo. Naquele contexto, responder às acusações é fundamentalmente uma questão de honra. Também, invariavelmente, nessa primeira leva de artigos, há notícias sobre realizações ou programas governamentais. Aos poucos, a retórica de Brizola vai tomando conta dos artigos, fazendo com que comecem a aparecer mais amiúde as metáforas, as expressões populares, além das analogias históricas. No tijolaço de 26/08/1984, por exemplo, intitulado Fins inconfessáveis, Brizola 
Intervenção política, imprensa e democracia:...

dessa maneira responde à campanha contra ele levada a efeito pelo Estadão e pelo $J B$ :

Como é natural, desde o início [a campanha] despertou suspeitas. Todos diziam nas ruas e rodas de conversa: 'Algo está por trás disso. Tem caroço nesse angu. Que diabo! Ficaram em silêncio durante 8 anos do Chagas e outros tantos da ditadura e agora, de repente, exigem e reclamam de tudo! Dar crédito a isso seria conceder demasiado espírito público a estes fariseus. (JB, 26/08/1984)

Ainda nessa primeira leva, nota-se um líder buscando desvencilhar-se de armadilhas, atuando fundamentalmente no campo do adversário e preocupado em firmar-se como autoridade legítima e responsável, que, acima de tudo, busca não comprometer o andamento da transição política capitaneada pelo governo e pelos líderes civis dos principais partidos. Não por acaso, seus artigos evitam temas de cunho mais ideológico ou programático e mesmo críticas frontais ao governo que ora bate em retirada.

A senha para a mudança de tom teve início com o advento do Plano Cruzado, no início de 1986, evento que na prática representa o início do governo de José Sarney - um presidente provisório eleito apenas para conduzir a transição. A excelente acolhida do plano econômico pela opinião pública o fez abandonar qualquer prurido político e partir para o ataque, caminhando célere para liderar a oposição. O tom necessariamente começou a subir.

Em 06/04/1986, Brizola fez chegar a público um tijolaço de outra natureza, no qual trata de um único tema. Nele, deixa de lado as birras cotidianas e ordinárias e parte para o ataque frontal não apenas contra o governo Sarney ou o plano cruzado, mas sim contra a iniquidade do domínio das oligarquias políticas que secularmente dominavam o país. Para isso, vale-se de um arsenal do seu aparato retórico que se encontrava pouco esquecido: o uso de exemplos históricos e de análises sociológicas para demonstrar como a sociedade brasileira, desde a sua formação, divide-se entre uma elite oligárquica amoral e o povão. E é com base nesse tipo de argumentação que se volta contra o Plano Cruzado, que é visto por Brizola como uma 
artimanha para favorecer o capital e saquear os salários do povo trabalhador. Dessa feita, estamos diante de uma liderança que saiu de uma posição defensiva para, pela via de um discurso ideológico, ocupar sua posição de líder nacional da esquerda oposicionista.

Em sucessivos artigos, naquele mesmo ano, Brizola aprofunda suas críticas ao novo governo e ao novo regime civil, visto por ele como ilegítimo. Em quatro artigos consecutivos, assinados entre 04 e 25 de maio, o governador do Rio solta o discurso para discutir questões amplas, com vistas a demarcar claramente o seu posicionamento no plano político nacional. Nos títulos dos tijolaços, percebe-se do que estamos falando: capitalismo inviável, síndrome da ilegalidade, sistema colonial e divisor de águas. Nada mais explícito dessa inflexão na linguagem de Brizola do que o trecho a seguir:

Do outro lado desse grande divisor de águas, está o povo brasileiro com suas penas e seu sofrimento. Aturdido, mas não convencido. E com ele, os que não se entregarão nunca e, por isso mesmo, levantam sua voz de advertência e protesto. Não é sem razão, pois, que este lado eja aquele que se encontra o governo do estado do Rio de Janeiro e o PDT. [...] Queiram ou não as elites brasileiras, da direita, ou essa suposta esquerda que hoje integra o sistema de dominação: nós somos a continuidade da história. (BRIZOLA, 1986, p. 7).

Dito isso, passemos agora a explorar um pouco os tijolaços do começo da década de 90, quando Brizola, depois de perder as eleições presidenciais do ano anterior, elege-se uma vez mais à governadoria do Rio de Janeiro e mantém-se como candidato trabalhista à presidência.

No pleito presidencial de 1989, esteve prestes a alcançar o segundo turno, perdendo por um percentual pequeno para o candidato petista, Luiz Inácio Lula da Silva. Nos tijolaços daquele ano e do ano seguinte, mantém-se coerentemente na posição de duro oposicionista do então presidente Fernando Collor de Mello.

Em 1990, quando da posse do novo presidente e do lançamento do plano Collor, Brizola concentra todas as suas baterias contra o governo. Faz as vezes de presidente nacional do seu partido e 
candidato a novo mandato ao governo estadual do Rio de Janeiro, adotando a estratégia de abordar fundamentalmente os temas nacionais, deixando de lado os estaduais. A larga vitória nas eleições de 1990 - ainda no primeiro turno - lhe deu fôlego para reafirmar seu nome no plano político nacional.

Nos anos seguintes, Brizola, investido uma vez mais do cargo de governador, pouco iria se valer dos tijolaços para prestar contas dos seus projetos de governo. Seriam as questões nacionais que tomariam conta de sua agenda e subordinariam suas decisões. Entre 1991 e 1992, promoveu uma reviravolta nas suas relações com o governo Collor, saindo da posição de um dos líderes oposicionistas para colaborador do governo no plano político-administrativo, ainda que costumasse demarcar as diferenças de projeto político no que concerne às privatizações levadas a efeito pelo novo presidente. Foi alto o preço político que Brizola pagou por essa colaboração, uma vez que passou a ser visto como aliado, ainda que circunstancial, de um presidente que veio a ser afastado da presidência por denúncias de envolvimento com a corrupção.

Brizola, por seu turno, via um complô de inspiração golpista na movimentação de amplos setores sociais - apoiados pela mídia - contra o presidente Collor e tomaria uma posição ambígua na crise que teve como desfecho o impeachment. Para o governador do Rio, era mister que se investigasse não apenas as denúncias contra o presidente, mas também as denúncias tanto contra o ex-governador de São Paulo Orestes Quércia (figura-chave do PMDB), como as dirigidas contra Roberto Marinho e as Organizações Globo. Nesse momento de ambiguidade, a oposição direta e frontal volta-se contra as Organizações Globo.

A saída de Collor do poder serviu de senha para um contínuo declínio do nome de Brizola como personagem central da vida política brasileira por dez anos. Seus tijolaşos, nos anos seguintes, acompanhariam esse declínio. 


\section{O que se diz nos tijolaços: inventário temático e projeto político}

Com base no que foi exposto, passemos agora a nos deter no universo de temas expostos nos tijolacos. Para tal, optamos pela seguinte metodologia: 1) foram classificados apenas os artigos de fundo, os mais importantes, deixando de lado as notícias e os pequenos comentários; 2) fixamos uma distinção entre temas político-administrativos e político-partidários-eleitorais; 3) o primeiro conjunto diz respeito a questões mais relacionadas à prestação de contas, à divulgação de programas de governo, às relações intergovernamentais; 4) o segundo, refere-se a temas como candidaturas /campanhas; vida partidária; análise política nacional; quadro internacional; doutrina trabalhista (histórico/nacionalismo); política econômica/planos econômicos. Por fim, dada a importância do tema para o conjunto de publicações, achamos por bem nos dedicarmos a um breve exame das relações com a mídia. Os resultados aqui apresentados dizem respeito a um número total de 150 artigos, divididos entre os períodos de 1984 e 1989 e de 1990-1994.

Acompanhemos dois gráficos que apresentam dados consolidados sobre os conjuntos Político-administrativo e Intervenção política.

Levantamento geral (1984-1994)

1. Prestação de contas/Administração/ Governo

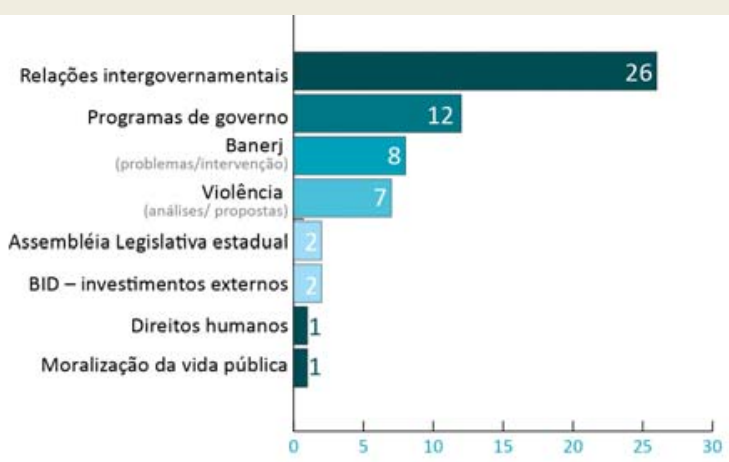

Anos 90, Porto Alegre, v. 18, n. 33, p. 15-40, jul. 2011 
Intervenção política, imprensa e democracia:...

Levantamento geral (1984-1994)

2. Intervenção política/ Candidaturas/Eleições

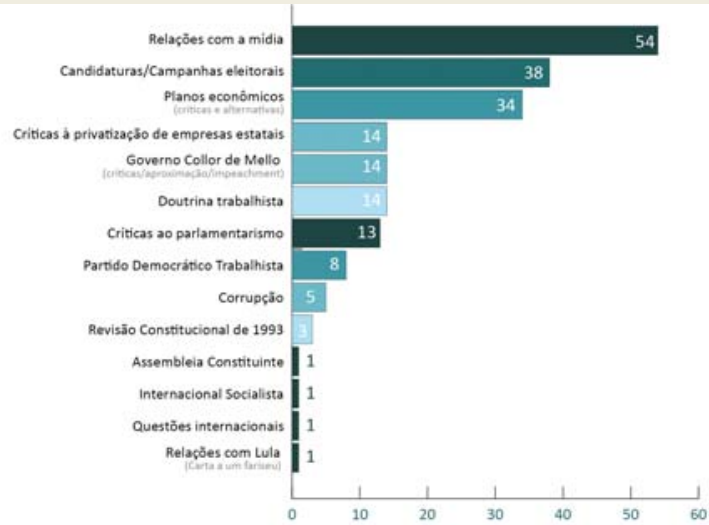

Os dados anteriores representavam uma boa mostra da pauta de questões tratadas por Brizola e da forma pela qual ele se valeu daqueles valiosos espaços na grande imprensa. Da leitura dos gráficos é possível afirmar o seguinte.

Neles, observa-se uma importante concentração em torno de poucos temas, o que nos sugere que seja possível pensar em tendências gerais e linhas de continuidade entre os dois períodos em tela (1984-1989 e 1990-1994). Em seu conjunto, os artigos dedicados à intervenção político-partidária superam largamente em número os dedicados às questões político-administrativas, o que, por si só, permite-nos inferir algo em torno do caráter típico dos tijolaços: para além da alegação inicial de que serviriam como canal de diálogo com povo do Rio de Janeiro para a apresentação de projetos e prestação de contas do governo, os artigos são marcados fundamentalmente como espaços de combate político e de resposta aos adversários.

Nesse contexto, é possível entender a ênfase anteriormente apresentada em temas como relações intergovernamentais, no primeiro conjunto, e nas relações com a mídia, no segundo. Com algumas modulações - diria mesmo, poucas - trata-se de atingir o mesmo objetivo: a da resposta dura e implacável aos que agem contra o Rio de Janeiro, no caso, o governo federal, durante os governos 
Sarney, Collor e Itamar, assim como aos jornalões e à Rede Globo, os quais, o segundo Brizola, desenvolviam campanhas diuturnas contra ele, seus governos e sua candidatura à presidência da República.

Dois outros aspectos relativos aos temas presentes nos tijolaços devem ser registrados para um melhor entendimento desses artigos no âmbito das estratégias políticas acionadas por Leonel Brizola nessa quadra particular da vida brasileira: os que dizem respeito aos temas de natureza estadual e aos de cunho político-institucional. Quanto aos primeiros, o que se observa nos textos dos tijolaços é que esses temas terminaram por assumir uma importância bastante secundária no conjunto dos artigos, ganhando inteligibilidade apenas se vistos sob uma perspectiva política mais ampla, nacionalizadora. Um exemplo marcante nesse sentido refere-se ao problema enfrentado pelo governo Brizola para sanear e colocar de pé novamente o Banco Estadual - o Banerj - problema esse, por sinal, que esteve na agenda de um sem número de governadores de estado na passagem dos anos 80 para os 90 . Via de regra, esses bancos terminaram sofrendo algum tipo de intervenção federal, de maior ou menor escala, até serem privatizados. Sobre esse tema, os vários tijolaços que vieram à luz pouco esclarecem o leitor sobre as condições específicas que deixaram o banco naquela situação de dificuldades. Em seu lugar, o que há é um discurso eivado de denúncias contra a perseguição política, a má vontade, e ao bloqueio político do governo federal contra sua administração.

O mesmo poder-se-ia dizer de um outro tema que lhe causaria enorme dor de cabeça: o da violência urbana. Uma vez mais as intervenções de Brizola apresentam-se genéricas, fugidias, respondendo de forma apressada a um problema que veio a ocupar generosos espaços na mídia contra ele e seu governo. Há de se examinar melhor as razões pelas quais o líder trabalhista, afastando-se de seu estilo, se mostra pouco incisivo em relação a esse problema em seus tijolaços. É possível pensar que, dessa maneira, reagisse no sentido de não convalidar a pauta imposta pela mídia.

Os tijolaços de Brizola também mostram-se de pouca valia para os que se colocam interessados em examinar as teses e proposições dos trabalhistas no contexto dos debates que giraram em torno da elaboração da nova constituição brasileira e o consequente reor- 
denamento político-institucional do país em meados dos anos 80 . $\mathrm{Na}$ ocasião, Brizola, já fora da governadoria estadual, termina por deixar esse papel a cargo das bancadas federais do partido. Algo bem diverso se deu quando esteve em pauta, nos anos de 1992-1993, a polêmica relativa à mudança do sistema de governo do presidencialismo para o parlamentarismo. Nesse caso, Brizola mostra-se motivado para entrar em cena e denunciar, em vários artigos, o que chama de a manobra do parlamentarismo. Nesse debate, vale-se de muitas armas do seu arsenal retórico e compõe um quadro significativo do que ele e seu partido propõem para a sociedade brasileira. Daí, é mister que acompanhemos sua linha argumentativa, tomando por base o tijolaço publicado em 27/12/1992, o último daquele ano.

Como dissemos anteriormente, o formato dos tijolaços variou com o tempo, acompanhando a trajetória de Brizola e o rumo dos acontecimentos políticos. Por vezes, o artigo apresentado perde o tom característico de crônica política para receber ares mais solenes, assumindo feições cuja principal marca é o investimento do autor em um único tema, deixando de lado comentários laterais ou mesmo acusações pessoais. Na nossa mostra de pesquisa, reunimos alguns desses tijolaços que fazem as vezes de manifestos políticos, nos quais o líder torna pública a diretriz geral com a qual sua corrente política deve enfrentar determinada questão. $\mathrm{Na}$ retórica dos tijolaços, esses manifestos apresentam alguns traços comuns, entre os quais o uso sistemático da genealogia histórica trabalhista como argumento de autoridade. Neles, o autor estabelece elementos de contraste entre os anos de criação e afirmação do trabalhismo varguista e os novos tempos pós-ditatoriais marcados pela crise, pela indefinição e pela ação conspiratória das elites contra o povo. Contra tudo isso, colocase o projeto trabalhista, o único que se identifica com a histórica luta popular.

No artigo em tela, intitulado Parlamentarismo: de novo, um casuísmo (JB, 27/12/1992), esse script se repete. O mote do tijolaço, ou seja o que lhe atribui sentido, é a crítica direta ao movimento parlamentarista no Brasil, visto por Brizola como "[...] mais um expediente cínico e traiçoeiro entre aqueles que as elites brasileiras têm utilizado para conservar o poder e evitar que a população defina, pela sua vontade soberana, os destinos do País." Segundo ele, essas mesmas elites têm 
agido historicamente, dentro do próprio sistema presidencialista, no sentido de invalidar ou mesmo enfraquecer o presidencialismo como instrumento de transformações sociais, frustrando as expectativas e os direitos do povo brasileiro. Tanto é, diz ele, que

[...] nos últimos 40 anos - desde a eleição de Vargas -, o Brasil não tem a chance de eleger um governo coerente, cuja expressão eleitoral se reflita na área parlamentar. Desde 1950, ou se elege um presidente com o Congresso já formado, ou se elege um presidente em meio a um mandato presidencial. Para um governante, sobreviver a um quadro desta natureza, só à custa de manobras, arranjos e concessões. Ainda mais agora, em meio a um sistema de comunicação avassalador, de natureza empresarial e monopolista, muito mais voltado para os interesses da manutenção do status quo do sistema econômico neocolonial do que preocupado em defender os valores nacionais e os direitos e aspirações da população. (JB, 27/12/1992)

Brizola via no próximo pleito, a se realizar em 1994, uma oportunidade ímpar para promover as alterações necessárias nesse estado de coisas, uma vez que seriam realizadas eleições simultâneas à presidência da República, ao Congresso Nacional - havendo a renovação de 2/3 das cadeiras do Senado Federal -, e ao governos de todos os estados. Daí, nas palavras de Brizola,

[...] o povo brasileiro poderá eleger um governo comprometido, acima de tudo, com a população e que conte com a maioria do Congresso e o apoio de um sólido conjunto de governadores para executar um programa de transformações que tire, finalmente, o nosso País da crise a que o levaram. (JB, 27/12/1992)

A campanha parlamentarista, registra o líder trabalhista, nada mais representa do que um casuísmo: um mecanismo de usurpação de um direito que negaram por tanto tempo ao povo brasileiro. Esse mesmo artifício, lembra ele, deu-se em 1961, quando seus artífices 
Intervenção política, imprensa e democracia:...

"precisaram esconder-se numa madrugada para violar a Constituição, a fim de impor aquele regime absurdo". Então, finaliza,

[...] seria impensável que a população fosse renunciar a essa chance, cassando a si própria o direito de instituir um governo que abra novos caminhos para o Brasil e para os brasileiros, deixando que, em seu lugar, ascendam ao poder os acordos, conchavos e arranjos parlamentares das elites brasileiras. (JB, 27/12/1992)

Ao longo da pesquisa, optamos por reunir esses manifestos sob a rubrica Doutrina Trabalhista. Neles, o autor dos tijolaços condensa algumas das mais importantes teses do chamado novo trabalhismo, o qual é apresentado à opinião pública como uma corrente política que se propõe a recuperar e renovar o programa nacional-estatista do trabalhismo dos anos 50 e 60. No exemplo de manifesto anteriormente assinalado, é possível perceber a maneira pela qual se dá esse duplo movimento de resgate e aggiornamento. Senão vejamos.

Como já registramos, Brizola utiliza-se largamente de argumentos de fundo histórico para reforçar, diríamos mesmo, reiterar seus posicionamentos políticos, afinal, dizia ele, os trabalhistas " [...] vêm de longe" e têm o papel de recuperar o "fio da história". No artigo em tela, há duas menções nesse sentido: a que se refere à eleição de Vargas em 1950, a última a produzir um verdadeiro presidencialismo, e a que diz respeito à implantação, às carreiras, do sistema parlamentarista, vista à época por Brizola como um embuste. Esses dois eventos históricos, de fundamental importância na construção da narrativa trabalhista, são citados como marcos temporais para situar o argumento central do autor: o novo embuste proporcionado pela campanha parlamentarista que se desenvolve tendo em vista o plebiscito sobre sistema de governo a se realizar no primeiro semestre de 1993. Nos termos fortes em que Brizola lida com seus adversários nos anos 90, percebe-se os ecos de suas palavras das lutas políticas desferidas contra esse mesmo inimigo - travestido de parlamentarismo - no início dos anos de 1960.

Para além dessa clara linha de continuidade entre esses dois tempos, Brizola aponta em seu manifesto antiparlamentarista distinções 
entre o antes e o agora. A principal novidade é a constituição de um "sistema avassalador de comunicação" a servir de base política à ação retrógrada das elites oligárquicas e das classes dominantes. Para o enfrentamento desse estado de coisas, a receita é mais ou menos a mesma da de 1960: a defesa do ideário trabalhista na constituição de um governo federal forte, popular e soberano capaz de realizar as necessárias mudanças de fundo no país. Neste manifesto, como de resto em todos os demais, Brizola detém-se nesse ponto, não segue adiante, não avança em proposições de cunho disruptivo e revolucionário que colocam em xeque a ordem vigente, como o fez às vésperas do golpe civil-militar de 1964, sob a alegação de que faltava legitimidade ao sistema político de então. Essa postura, cabe observar, mostra-se coerente com a linha adotada pelo partido trabalhista que, desde a divulgação da Carta de Lisboa, de junho de 1979 - considerada o documento fundador da agremiação - tornara explícita a defesa da via democrática para responder aos desafios do país?. Por caminhos diversos, outras correntes das esquerdas brasileiras também fizeram o mesmo.

\section{A mídia como alvo preferencial}

Nesta seção, não cabe discutir se Brizola e os projetos de seu partido foram ou não prejudicados, perseguidos ou combatidos pelos diferentes veículos de comunicação. Ao invés disso, o foco de análise é a narrativa construída por Brizola nos tijolaços a respeito das relações com a mídia e de como o líder trabalhista se vale delas para fortalecer suas posições no campo político.

Nos tijolaços, a mídia é vista costumeiramente como tendenciosa e manipulada por grandes grupos privados. Daí, sua falta de compromisso com os princípios de verdade e justiça e seu desrespeito ao senso crítico do cidadão. Vinculada ao Governo Federal e sob a tutela do poder econômico, ela aparece como parte integrante das elites políticas do país responsáveis pela entrega do patrimônio público e das riquezas nacionais ao capital estrangeiro, pela exploração das classes desfavorecidas e, principalmente, pela tentativa de deturpar e manipular, em suas palavras, a consciência nacional. 
No Rio de Janeiro, os artigos de Brizola eram publicados nos dois principais veículos de comunicação - Jornal do Brasil e $O$ Globo - , que eram também seus principais alvos de críticas. Ambos apresentam-se nessas narrativas marcados por um abuso de poder, por enganar a população através da utilização de fatos inexistentes, pela ausência de escrúpulos, pelo tráfico de influência e por um tratamento desrespeitoso e discriminatório ao governo e à população do Rio de Janeiro.

A existência de um conflito entre Leonel Brizola e a mídia já foi apontada em diversas obras e trabalhos acadêmicos ${ }^{10}$, assim como se faz presente no imaginário popular e na memória construída acerca da trajetória política do líder trabalhista. No entanto, curiosamente as fontes que mais explicitam esse embate ainda não foram utilizadas como materiais de pesquisa. A publicação dos tijolaços representa, sem dúvida, um caminho escolhido pelo político como estratégia de enfrentamento e confronto para com a grande imprensa. A mídia é, ao mesmo tempo, a arma, o meio, o campo de batalha e o seu próprio inimigo. Os jornais transformam-se, a partir da publicação dos artigos, em uma ferramenta de defesa, ataque e promoção pessoal de Brizola. Os periódicos são utilizados como instrumento para a crítica dos mesmos. A imprensa configura-se, então, em porta-voz do lider trabalhista não só para defender a si próprio e à sua administração como para divulgar suas ideias e os princípios do novo trabalbismo.

É interessante observar como Brizola, ao longo de seus cinquenta anos de vida política, colocou-se muitas vezes na posição de contendor, acumulando antagonismos ora ideológicos, ora partidários, ora administrativos. Foi por meio dessa atitude de combate que Brizola forjou uma imagem de homem público forte e destemido, capaz de lutar com vigor pelas suas ideias e pelos seus projetos de poder. Em relação à mídia, não havia de ser diferente. Duelos e diálogos foram travados ininterruptamente entre os dois atores. De um ângulo, a imprensa como rival, inimiga. De outro, aliada, parceira. Um contrato dicotômico que, sem dúvida, contribuiu muito para a construção da figura política de Leonel Brizola e do imaginário acerca de sua personalidade.

Como já era de se esperar, as Organizações Globo e seu presidente Roberto Marinho aparecem na narrativa dos tijolaços 
como o grande e principal inimigo de Brizola, de seu partido e de seu governo. Tal inimizade, por mais que valorizada e incentivada pelo autor dos artigos, não se desenvolveu de maneira aleatória, uma vez que $O$ Globo, em oposição a Brizola, tal como havia feito com outras figuras centrais do trabalhismo, Getulio Vargas e João Goulart. Esse posicionamento também era expresso na TV Globo, o mais importante e influente canal de televisão naquela época e até os dias de hoje. A conquista inédita de um Direito de Resposta na Justiça por Leonel Brizola, apresentado através da leitura de uma carta no Jornal Nacional, sob a imponente voz do apresentador Cid Moreira, ilustra o sabor amargo dessa relação ${ }^{11}$.

A Globo representava para ele, metaforicamente, "[...] um polvo gigantesco que estende seus tentáculos por toda parte" "12. Um poder avassalador que detinha o monopólio dos meios de comunicação concedido, estruturado e fortalecido durante o regime ditatorial, servindo a seus fins e propósitos. "Os senhores das Organizações Globo usaram por mais de 20 anos o cachimbo da ditadura"13, afirma Brizola ao defender a ideia de retroalimentação do veículo informacional e do sistema. Um jornal marcado por autocensura com o objetivo de intrigar a opinião pública contra a sua administração.

Dentre as inúmeras expressões utilizadas na linguagem dos tijolaços para se referir ao poder Global e à família Marinho, algumas são expressivas e se apresentam como protagonistas desse duelo e, ao mesmo tempo, diálogo: "Monopólio avassalador"; "Império do Mal"; "Máquina Demoníaca"; "Conglomerado descomunal”; "Gigante de pés de barro". Os ataques à Rede Globo, a seu proprietário e a distintos veículos, giram em torno da possibilidade desse "braço midiático" monopolizar e manipular a divulgação das informações e, em associação ao Governo Federal, levar adiante um "processo de dominação colonial" voltado para a entrega da indústria nacional ao capital estrangeiro, pela "leiloagem" do patrimônio público e pelo desemprego. A mídia, sob o prisma das Organizações Globo e pelo olhar de Leonel Brizola, não passaria de "um boletim de negócios, um instrumento de pressão e de lobbies em favor de grupos". A relação entre o então governador e o veículo se acirra gradualmente consolidando-se em ataques cada vez mais ásperos e com tons de 
Intervenção política, imprensa e democracia:...

denúncia. Como aparece em trecho do tijolaço "O estigma do golpismo”, publicado em 28/03/1993 no Jornal do Brasil:

O Globo devia lavar-se com água e sabão antes de falar em liberdade de imprensa. Apoiou a implantação da ditadura, a censura aos jornais, as cassações, as perseguições e a tortura.

O Jornal do Brasil, o outro grande veículo de comunicação carioca, que nos anos 60/70 compunha um perfil liberal, manteve uma atitude mais ambígua do que $O$ Globo nas suas relações com Brizola. Em 1982, por exemplo, esteve ao seu lado nas denúncias de fraude contra a sua eleição para o governo do estado; dois anos, depois, porém, manteve uma dura campanha contra o governador, ao lado do Estado de São Paulo. Por fim, nos anos 90, quando da aproximação de Brizola com o governo Collor de Melo, o JB adotou uma linha editorial mais branda em relação a Brizola.

Nesse jogo envolvendo O Globo, JB e Brizola, há um elemento bem próprio e característico daquele triângulo: nos momentos de maior radicalização do primeiro, ou seja no começo do governo Sarney e durante a crise do governo Collor, o $J B$ punha-se em posição oposta, como que a tentar firmar posição junto aos que defendiam Brizola. Daí, cremos ser essa a razão de ter sido o $J B$ o principal veículo de publicação dos tijolaços ao longo de quase quinze anos.

O conflito entre Leonel Brizola e a mídia, centralizado na relação com as Organizações Globo, se desenvolve nos tijolaços a partir de uma dicotomia calcada na autovitimização do político diante da atuação dos meios de comunicação que são desenhados como espécies de vilões. Em seus artigos, matérias divulgadas n’O Globo sobre o seu governo e sua administração se transformam em fatos inexistentes, calinias, infâmias, achincalhes e se apresentam impregnadas de distorçoes e malicias com o simples objetivo de questionar, escarnecer, enfraquecer e destruir a imagem do então governador do estado do Rio de Janeiro. Nas palavras de Brizola, esse veículo de comunicação visaria unicamente a lhe retirar do poder e da cena política.

A narrativa brizolista nos tijolaços, tal como a linguagem mítica, opera por meio de contrastes, por oposições ${ }^{14}$. De um lado, está a vítima em seu passado de lutas no passado, de sofrimento no exílio 
e de desprendimento heróico no presente. De outro, um sistema dito corrupto e formado pela aliança entre um Governo Federal autoritário e voltado para a manutenção dos interesses das elites políticas e um setor midiático subordinado ao poder econômico e responsável pela tentativa de manipulação da sociedade.

A análise dos tijolaços possibilita uma ressignificação do contrato dicotômico estabelecido e enfatizado por Leonel Brizola em sua relação com a mídia, na medida em que, mais do que indicar sua posição de vítima passiva de um grande sistema, esses artigos dão curso a uma narrativa de vitimização que lhe serve de arma para enfrentar a imprensa, para fortalecer sua imagem de homem público e de seu partido e, principalmente, para angariar o apoio da população. É possível dizer, portanto, que Brizola se alimentava do meio que tanto criticava. A mídia, através da publicação dos tijolaços, colocou-se como o veículo no qual o político poderia questionar a conduta, os valores e as funções dela mesma. Ou seja, a imprensa tornou-se nas mãos no líder trabalhista uma ferramenta para combater a própria. E o posicionamento vitimizado, construído ao longo de seus textos, uma das formas encontradas para utilizar tal instrumento.

\section{Considerações finais}

A morte de Leonel Brizola teve grande destaque na semana passada. No farto material publicado pela imprensa ficou faltando um dado relevante - sua relação com a própria imprensa. Relação conflituada, trepidante. Brizola foi o político que melhor soube tirar partido dos meios de comunicação na segunda metade do século passado. [...] Sem que isso signifique um endosso às suas posições nos enfrentamentos com a mídia, é imperioso reconhecer que Brizola foi o único político brasileiro com coragem para encarar e confrontar o poder da grande imprensa. (Alberto Dines, Observatório da imprensa. 29/06/2004) ${ }^{15}$ 
O depoimento do jornalista Alberto Dines, publicado dias depois da morte de Leonel Brizola, ajuda-nos a situar e explorar um pouco mais algumas das questões que levantamos neste texto. Como vimos acima, não há como acompanharmos a carreira de Brizola sem nos determos nas suas "trepidantes" relações com os meios de comunicação. A título de hipótese, é possível afirmar que um marco nessas relações foi a Campanha da Legalidade, momento no qual se atirou no combate ao golpismo civil-militar. Em seguida, sua ascensão meteórica rumo ao centro do poder foi acompanhada pari passu pela mídia.

Nas décadas de 1980 e 1990, Brizola, à frente do PDT e peça importante no xadrez político da democratização brasileira, resolveu registrar seu ponto de vista em jornais da grande imprensa que o viam como inimigo político. Os tijolaços foram criados exatamente para isso: para dar livre curso à sua palavra, às suas teses e ao projeto trabalhista de poder.

Esquematicamente, poderíamos dividir o conjunto dos tijolaços em três categorias: informes, libelos e manifestos. Nos informes, Brizola noticia realizações de governo, divulga avisos e esclarecimentos à população, desenvolve comentários curtos sobre um tema, aborda questões variadas, ao estilo da crônica. Do ponto de vista numérico, os relatos representam uma minoria no conjunto dessas publicações, uma vez que, como vimos anteriormente, o líder trabalhista, em especial no seu segundo mandato na governadoria do Rio de Janeiro, pouco voltou-se para produzir relatos de prestação de contas ou mesmo comentários relativos à gestão estadual. $\mathrm{Na}$ narrativa brizolista, há claro predomínio de libelos e manifestos.

Como peças de acusação, os libelos apresentam-se como ferramentas de ataque de Brizola aos seus adversários políticos, ao Governo Federal, aos setores midiáticos e, em especial, às Organizações Globo. Ao mesmo tempo, são instrumentos de defesa recorridos pelo político para a proteção e preservação de sua imagem, popularidade e apoio civil diante das denúncias e críticas daqueles que o atacam. Os libelos são, portanto, a arma e o escudo dos tijolaços, sendo marcados por um tom moralista e permeados pela indignação. A valorização do conflito com a mídia e uma autorrepresentação vitimizada são utilizados como estratégias recorrentes do discurso de Brizola. 
Nos manifestos, os programas e plataformas do novo trabalhismo são expressos e o passado nacional-varguista é resgatado. O ideário, projeto e objetivos trabalhistas fazem-se presentes através da valorização do mercado interno, da ruptura com a intervenção do capital estrangeiro, da luta por um Estado democrático, do incentivo ao sistema educacional e da melhoria dos serviços públicos. A ideologia nacionalista apresenta-se como fio condutor da linguagem desse tipo de tijolaço, mediante a utilização de termos e expressões como nação, povo brasileiro, soberania e consciência nacionais, desenvolvimento e progresso.

Para concluir, não há como deixar de mencionar o outro lado dessa história, ou seja, a maneira pela qual a grande imprensa lidou com o líder trabalhista. Por ora, fiquemos com breves considerações a respeito das razões pelas quais a grande imprensa resolveu vender generosos espaços para Brizola, publicando-os em seções nobres dos jornais. Para além das óbvias questões de cunho comercial, por certo importantes, há de se pensar também em dois pontos: nos ganhos simbólicos que os jornais puderam obter ao abrir suas páginas ao seu contendor, forjando assim uma imagem de veículos democráticos e abertos ao contraditório; ${ }^{16}$ e no contexto político próprio pelo qual esses artigos foram publicados, cuja marca predominante, para vários autores, foi a invenção e a indeterminação democráticas. ${ }^{17} \mathrm{Os}$ tijolaços, ao nosso ver, são um bom exemplo desses novos tempos.

\section{Political action, media and democracy: Leonel Brizola's tijolaços}

Abstract: Leonel Brizola, in the 1980's and 1990's, using the prestige of his name along with fellow party members, raised funds to systematically publish articles in the Brazilian press, which came to be known as tijolacos or tijolões. For about fifteen years, Brizola used the tijolaços to fight his political enemies, were they right or left, to show his administration as governor of Rio de Janeiro, or to spread the nationalist ideas of "New Labour". On various occasions, the texts signed by Brizola came into collision with the newspapers editorial that published his tijolaços. In this article, along with presenting a research guide in order to analyze this important set of documents, we address some specific issues that relate to Brizola relations with the media, and the manner in which his statements were the basis for the construction of his own speech within the brazilian democratization process.

Keywords: Political history, Leonel Brizola, Brazilian Democratization Media. 
Intervenção política, imprensa e democracia:...

\section{Notas}

${ }^{1}$ Este texto é resultado de palestra proferida no XV Congresso Internacional da Federação Internacional de Estudos da América Latina e do Caribe (FIEALC), realizado em Valência, Espanha, em julho de 2011. A pesquisa é financiada pelo CNPq.

2 Para o estudo da trajetória política de Leonel Brizola, BANDEIRA (1979), KUHN, (2004) e LEITE FILHO (2008). Conforme movimentação de Brizola no pré-64 em FERREIRA (2003; 2009), BALDISSERA (2005) e SZATKOSKI (2003). Sobre o fenômeno do brizolismo no Rio de Janeiro, ver obra referência de SENTO SÉ (1999). Sobre o novo trabalhismo, SENTO-SÉ (2004, p. 49-76) e (2007, p. 429-450), VAINFAS (2007, p. 479-502), FREIRE (2007) (2008) e COSTA (2009). Para uma análise ampla sobre o trabalhismo e sobre a trajetória de Brizola no Rio de Janeiro, ver GOMES (2004) e FERREIRA (org.) (2008).

${ }^{3}$ Conferir BRIZOLA (2004) e LEITE FILHO (2008, p. 228).

${ }^{4}$ Disponível em www.pdt.org.br/índex/articles/tijolaco-para-principiantes. Acesso em 05 de jun. 2011. Outro montante é apresentado por Fernando Brito, assessor de Brizola, em depoimento à jornalista Mônica Rodrigues. Segundo Brito, Brizola publicou cerca de 600 tijolaços entre 1984 e 2004. Ver RODRIGUES.

${ }^{5}$ RODRIGUES (2008, p. 83-84) e LEITE FILHO (2008, p. 228).

${ }^{6}$ Disponível em www.tijolaco.com. Acesso em 20 de nov. de 2011

${ }^{7}$ Conferir reflexões em torno da influência do protestantismo luterano em Brizola em SENTO-SÉ (1999, p. 60-61).

${ }^{8}$ Disponível em www.pdt.org.br/index.php/articles/tijolaço-para-principiantes. Acesso em 10 de nov. de 2011.

9 Sobre o significado Congresso de Lisboa, conferir em SENTO SÉ (2007, p. 229-250).

${ }^{10}$ Sobre o tema, conferir RODRIGUES (2008, p. 68-94).

${ }^{11}$ Ver http:/ / www.youtube.com/watch?v=ObW0kYAXh-8

12 Jornal do Brasil, 19 de outubro de 1986.

${ }^{13}$ Jornal do Brasil, 19 de outubro de 1986.

${ }^{14}$ A respeito do uso da linguagem mítica ver a obra clássica de GIRARDET (1987). Com base em GIRARDET (op.cit)., José Murilo de Carvallo assim descreve a forma pela qual Brizola manipula os mitos da política. "Nos 25 anos em que luta pela presidência da República, Brizola vem tentando manipular dois dos mais comuns mitos da política, o do salvador e o do complô. Em sua visão, ou na visão que procura vender, o Brasil se apresenta sempre na situação de impasse político cuja única saída reside na aceitação de sua liderança, de sua chefia. Trata-se de um messianismo que pode ter raízes em sua formação protestante, mas que certamente também se alimenta na tradição caudilhesca e positivista gaúcha, já encarnada por figuras como Júlio de Castilhos e Getúlio Vargas. O Messias, a Força da Luz, está sempre em luta contra o Reino das Trevas". (CARVALHO, 1998). 
${ }^{15}$ Publicado em RODRIGUES (2008, p. 92).

${ }^{16}$ Sobre o tema da participação da mídia na transição e na consolidação democrática no Brasil, ver ABREU e LATTMAN-WELTMAN (2006, p. 67-101).

${ }^{17}$ A noção "invenção democrática" baseia-se em LEFORT (1991) e (2001). Conferir "invenção democrática brasileira"em OLIVEIRA e RIZEK (Orgs.), (2007) e SANTOS (2006).

\section{Referências}

ABREU, Alzira Alves de; LATTMAN-WELTMAN, Fernando. Uma instituição ausente nos estudos de transição: a mídia brasileira. In: ABREU, Alzira Alves de (Org.) A democratização no Brasil: atores e contextos. Rio de Janeiro: Editora FGV, 2006, p. 67-101.

AZEVEDO, Flavia. Tijolaços: A mídia como Arma, Meio, Campo de Batalha e Inimigo Político. Rio de Janeiro, CNPq/CPDOC, Projeto de iniciação científica, 2010.

BALDISSERA, Marli de Almeida. Onde estão os grupos de onze. Os comandos nacionalistas na região do Alto Uruguai - RS. Passo Fundo, UPF, 2005.

BANDEIRA, Moniz. Brizola e o trabalhismo. Rio de Janeiro: Civilização Brasileira, 1979.

BRIZOLA, Leonel de Moura. Leonel Brizola: perfil, discursos e depoimentos (1922-2004). Porto Alegre: Assembleia Legislativa do Estado do Rio Grande do Sul. (Col. Perfis Parlamentares, n. 8, 2004).

CARVALHO, José Murilo de. Eleição em tempos de cólera. Jornal do Brasil, 16/07/1989. In: _. Pontos e bordados: escritos de história e política. Belo Horizonte: Editora UFMG, 1998, p. 343-348.

COSTA, Izabel Cristina Gomes da. Em busca do paradigma perdido: as esquerdas brasileiras e a crise do socialismo real. Nitéroi, Programa de Pós-Graduação em História da UFF. (Tese de doutorado). 2009.

FERREIRA, Jorg. Esquerdas no panfleto. A crise política de 1964 no jornal da Frente de Mobilização Popular. Anos 90. Porto Alegre, v. 16, n. 29, p. 81-124, 2009.

. O imaginário trabalhista. Getulismo, PTB e cultura política popular. Rio de Janeiro: Civilização Brasileira, 2005.

FERREIRA, Marieta de Moraes (Org.) (2008). A força do povo. Briz̧ola e o Rio de Janeiro. Rio de Janeiro: Editora da FGV, 2008.

FREIRE, Américo. Novo sindicalismo e movimentos sociais. In: FERREIRA, Marieta de Moraes (Org.). A força do povo. Brizola e o Rio de Janeiro. Rio de Janeiro: Editora da FGV, p. 128-150, 2008.

Reconstruindo Brizola: esquerda armada e novo trabalhismo: notas de pesquisa. Rio de Janeiro: Anais do Seminário Regional Sudeste de História Oral, 2007. 
Intervenção política, imprensa e democracia:...

GIRARDET, Raoul. Mitos e mitologias políticas. São Paulo: Companhia das Letras, 1987.

GOMES, Angela de Castro. Brizola e o trabalhismo. Anos 90. Porto Alegre, v. 11, n. 19/20, p. 11-20, 2004.

KUHN, Dione. Brizola: da legalidade ao exílio. Porto Alegre: RBS publicações, 2004.

LEFORT, Claude. A invenção democrática: os limites da dominação autoritária. Belo Horizonte: Autêntica Editora, 1983.

- Pensando o político: ensaios sobre democracia, revolução e liberdade. Rio de Janeiro: Paz e Terra, 1994.

LEITE FILHO. F. C. El caudilho: Leonel Brizola: um perfil biográfico. São Paulo: Editora Aquariana, 2008.

OLIVEIRA, Francisco de; RIZEK, Cibele S. (Orgs.). A era da indeterminação. São Paulo: Boitempo Editorial, 2007.

NEVES, Lucília de Almeida. PTB: do getulismo ao reformismo (1945-1964). São Paulo: Marco Zero, 1989.

RODRIGUES, Mônica. Imprensa: uma relação de amor e ódio. In: FERREIRA, Marieta de Moraes (Org.). A força do povo. Brizola e o Rio de Janeiro. Rio de Janeiro, Editora da FGV, 2008, p. 68-94.

SANTOS, Wanderley Guilhermes dos. Horizonte do desejo: instabilidade, fracasso coletivo e inércia social. Rio de Janeiro: Editora FGV, 2006.

SENTO SÉ, João Trajano. As várias cores do socialismo moreno. Anos 90. Porto Alegre, v. 11, n. 19/20, p. 49-76, 2004.

- Brizolismo: estetização da política e carisma. Rio de Janeiro: Espaço e Tempo/FGV, 2009.

. Um encontro em Lisboa. O novo trabalhismo do PDT. In: FERREIRA, Jorge; REIS, Daniel Aarão (Org.). Revolução e democracia (1964-...). Rio de Janeiro: Civilização Brasileira. (Coleção As esquerdas no Brasil, v. 3), 2007, p. 429-50.

SZATKOSKI, Elenice. Os grupos dos Onæe: uma insurreição reprimida. Passo Fundo, UPF, 2003.

VAINFAS, Ronaldo. A luz própria de Leonel Brizola: do trabalhismo getulista ao socialismo moreno. In: FERREIRA, Jorge; REIS, Daniel Aarão (Org.). Revolução e democracia (1964-...). Rio de Janeiro: Civilização Brasileira, (Coleção As esquerdas no Brasil, v. 3), 2007, p. 479-502.

Recebido em 07/02/2012.

Aprovado em 07/03/2012. 